\title{
IMPLEMENTATION OF CAREER GUIDANCE SERVICES FOR SENIOR HIGH SCHOOL IN DETERMINING MAJOR AT COLLEGE LEVEL
}

\author{
Saiful Akhyar Lubis, Abdurrahman, Rahmi Yasirna \\ Pascasarjana Universitas Islam Negeri Sumatera Utara, Indonesia \\ saifulakyarlbs@uinsu.ac.id, abdurrahman@uinsu.ac.id.,rahmiyasirna@gmail.com
}

Received: 15-06-2019 Revised: 10-10-2019 Accepted: 05-11-2019

\begin{abstract}
The purpose of this study was to determine the preparation of student career guidance services, the implementation of student career guidance services, and the supporting and inhibiting factors of student career guidance services at Al-Azhar High School Medan. This study uses a qualitative method with descriptive type that is to describe the object of research as itself. Data sources are school principals, guidance and counseling teacher, and Al-Azhar Plus High School students in Medan. The results showed that: (1) Preparation of career guidance services in class XII students at AlAzhar Plus High School Medan in determining majors to lecture levels through the first, the existence of a checklist of problems (DCM) that is used to determine the extent to which students have confusion about his career goals. Second, through testing the scholastic aptitude test (TBS). From the results of this test students also know the results of the test and know their abilities. (2) The form of implementing career guidance services through three programs are; First: information services, second: information gathering visits at various tertiary institutions, third: group or individual discussions.
\end{abstract}

Keywords: Career Guidance, Senior High School, Human resources, Teacher Counseling

\section{Abstrak}

Penelitian ini menggunakan metode kualitatif dengan jenis deskriptif yaitu menggambarkan objek. penelitian apa adanya. Sumber data adalah kepala sekolah, guru Bk, dan peserta didik SMA Plus Al-Az̧har Medan. Hasil penelitian menunjukekan bahwa: (1) Persiapan layanan bimbingan karir pada siswa kelas XII di SMA Plus Al-Az̧har Medan dalam menentukan jurusan ke jenjang perkuliahan melalui pertama, adanya daftar cek masalab (DCM) yang di gunakan untuk. mengetahui sejauh mana siswa memiliki kebingungan akan tujuan karimya. Kedua, melalui uji coba tes bakat skolastik. (TBS). Dari hasil tes ini siswa juga mengetahui hasil dari tes dan mengetahui kemampuannya masing-masing. (2) Bentuk pelaksanaan layanan bimbingan karir melalui tiga program yaitu Pertama: layanan informasi, kedua: kunjungan pengumpulan informasi di berbagai perguruan tinggi, ketiga: diskusi kelompok/individual.

Kata Kunci: Bimbingan Karir, Sekolah Menengah Atas, Sumber daya Manusia, Konseling Guru. INTRODUCTION

Education is an important thing in life, this statement means that every human has right to education and develop in it, education will never run out ${ }^{1}$. Education in general is a

${ }^{1}$ Mofareh Saeed Alkrdem and Abdulaziz Saeed Alqahtani, 'Educational Management in the Light of Islamic Standards', Journal of Education, Society and Behavioural Science, 12 February 2016, 1-9, https://doi.org/10.9734/BJESBS/2016/22671; Achmad Asrori, 'Contemporary Religious Education Model on 
process in developing each individual and to carry on his $\operatorname{life}^{2}$. College is educational institution where students can develop their potential and talents and enhance their academic abilities in depth according to their major ${ }^{3}$. This is the reason that senior high school after graduating is expected to continue their study to the higher level. The vision of univeristy is to prepare students become members of the community who can apply their knoledge, create knowledge and professionals in their fields ${ }^{4}$. Nevertheless the phenomenon in university that many students feel wrong in choosing their major. Even though choosing majors can be determined before they graduate from senior high school ${ }^{5}$.

Education can be said effective and efficient, if everyone that involved in education and be able to understand individual behavior, at the same time they can apply their behavior effectively, so that, one of the most important components in implementation of education is guidance and counseling ${ }^{6}$. Mc Daniel believes that: "Counseling is a series of face-to-face meetings with individuals that are shown in providing assistance for him to be able to adjust himself more effectively to himself and environment ${ }^{7} . "$

Based on the above understanding, the researcher concludes that guidance and counseling is a process of providing assistance carried out by expert (counselor) to client or several people, so that, the person being mentored can develop itself and independently. The purpose of guidance and counseling in general is individual assistance to develop themselves optimally in accordance with stages and predisposition they have (such as basic abilities and talents), various backgrounds (such as existing backgrounds, including family background, education, social economic status) and in accordance with the positive guidance of environment ${ }^{8}$.

There are four fields of counseling guidance, consisting of: (1) personal guidance; (2) social guidance; (3) tutoring; and (4) career guidance. One of the fields related to careers is

the Challenge of Indonesian Multiculturalism', JOURNAL OF INDONESIAN ISLAM 10, no. 2 (1 December 2016): 261-84, https://doi.org/10.15642/JIIS.2016.10.2.261-284.

${ }^{2}$ Idi Abdullah and Safarina, Etika Pendidikan, Keluarga, Sekolah Dan Masyarakat, Cet. 2 (Jakarta: PT Raja Grafindo, 2015); A. Rusdiana, Konsep Inovasi Pembelajaran (Bandung: Pustaka Setia, 2014).

${ }^{3}$ Yedi Purwanto et al., 'Internalisasi Nilai Moderasi Melalui Pendidikan Agama Islam Di Perguruan Tinggi Umum', EDUKASI: Jurnal Penelitian Pendidikan Agama Dan Keagamaan 17, no. 2 (31 August 2019), https://doi.org/10.32729/edukasi.v17i2.605.

${ }^{4}$ Siti Asiah.T and Herson Anwar, 'College Students' Perception about the Implementation of Democratic and Humanist Learning Model in State Islamic Institute (IAIN) Sultan Amai Gorontalo', Nadwa 12, no. 2 (7 January 2019): 273-92, https://doi.org/10.21580/nw.2018.12.2.2713; PARDOMUAN NJM SINAMBELA, 'Kurikulum 2013 Dan Implementasinya Dalam Pembelajaran', Generasi Kampus 6, no. 2 (2017).

${ }^{5}$ Kadek Hengki Primayana, 'Manajemen Sumber Daya Manusia Dalam Peningkatan Mutu Pendidikan Di Perguruan Tinggi', Jurnal Penjaminan Mutu 1, no. 2 (2016): 7-15.

${ }^{6}$ Choirul Mahfud, 'Evaluation of Islamic Education Curriculum Policy in Indonesia', Premiere Educandum: Jurnal Pendidikan Dasar Dan Pembelajaran 9, no. 1 (2019): 34-43; Moh. Wardi, Ismail Ismail, and Ali Makki, 'Perbandingan Pendidikan; Pemahaman Simbolis Dan Substantif PAI Di Madrasah Dan PAI Di Sekolah Umum', Nidhomul Haq: Jurnal Manajemen Pendidikan Islam 4, no. 1 (7 March 2019): 23-33, https://doi.org/10.31538/ndh.v4i1.104.

${ }^{7}$ Desmita, Psikologi perkembangan (Jakarta, Indonesia: PT Remaja Rosdakarya, 2013); Anja Plumeyer et al., 'Measuring Brand Image: A Systematic Review, Practical Guidance, and Future Research Directions', Review of Managerial Science 13, no. 2 (1 April 2019): 227-65, https://doi.org/10.1007/s11846-017-0251-2.

${ }^{8}$ Muhibbin Syah, Psikologi Pendidikan dengan pendekatan baru, 18th ed. (Bandung: Remaja Rosdakarya, 2013). 
career guidance 9 . Career guidance according to Utoyo are: "Activities and assistance services to students with the aim of gaining adjustment, understanding of the world of work and developing career planning. By giving career guidance, students will get help, the first, an understanding of their abilities, recognition of various work, well preparation for entering the work, placement in accordance with certain fields of work, problem solving related to work ${ }^{10 "}$

While Hornby argues, a career is "professional work ${ }^{11 "}$. According to Faqih, that Islamic career guidance is. "The process of providing assistance to individuals, so that, in the process of finding work and work is always in accordance with the provisions and instructions of God, so that, they can achieve happiness of life in the world and hereafter. Career guidance is an effort to help students in the process of making decisions about career or major that affects their lives in the future ${ }^{12} . "$

Based on this understanding, career guidance is an effort to help students in making decisions about career or job that affect their life in the future. During senior high school is an important time to determine a better future. Generally, they can not be independent, they still need help from others to get independence ${ }^{13}$. The task of students at this time is to choose or determine majors that will be chosen when entering college, in order to plan a future career. Through career guidance, students will get assistance to finalize the preparation of choosing major and ways of thinking, according to the conditions of each individual. Career guidance at school is needed, so that, students can make judgments and assessments appropriately. And to overcome career problems and strategies in order to finalize the ability to choose, plan careers and develop students' careers.

\section{THEORY}

\section{Career Guidance Services}

Career guidance is one field in counseling guidance. In the English dictionary, Guidance or leadership is the word origin "guide", which is interpreted as follows: showing the way, leading, conducting, giving advice. The term Guidance in Indonesian is the same

\footnotetext{
${ }^{9}$ Niki Alma Febriana Fauzi and Ayub Ayub, 'Fikih Informasi : Muhammadiyah’s Perspective on Guidance in Using Social Media', Indonesian Journal of Islam and Muslim Societies 9, no. 2 (25 December 2019): 267-93, https://doi.org/10.18326/ijims.v9i2.267-293; M. Fuad Anwar, Landasan Bimbingan Dan Konseling Islam (Deepublish, 2019).

${ }^{10}$ Darimis Darimis, 'Rem-Bekas (revolusi Mental Berbasis Konseling Spritual Teistik): Upaya Membangun Generasi Berkarakter Fast (fathonah, Amanah, Siddiq, Dan Tabligh)', Ta'dib 18, no. 1 (17 October 2016): 47-56, https://doi.org/10.31958/jt.v18i1.277; Agus Riyadi, 'Bimbingan Dan Konseling Islam Dalam Mengatasi Krisis Spiritual Akibat Dampak Abad Modern (Studi Pada Lembaga Bimbingan Dan Konsultasi Tasawuf Kota Semarang)', Konseling Religi: Jurnal Bimbingan Konseling Islam 9, no. 1 (2018).

11 Netrawati Netrawati, Khairani Khairani, and Yeni Karneli, 'Upaya Guru BK untuk Mengentaskan Masalah-Masalah Perkembangan Remaja dengan Pendekatan Konseling Analisis Transaksional', Islamic Counseling: Jurnal Bimbingan Konseling Islam 2, no. 1 (21 July 2018): 79-90, https://doi.org/10.29240/jbk.v2i1.463.

12 Laelatul Anisah, 'Kompetensi Profesional Konselor Dalam Penyelenggaraan Penelitian Tindakan Bimbingan Dan Konseling', JURNAL KONSELING GUSJIGANG 2, no. 1 (3 August 2016), https://doi.org/10.24176/jkg.v2i1.557; Baidi Bukhori, 'Dakwah Melalui Bimbingan Dan Konseling Islam', Jurnal Konseling Religi 5, no. 1 (2014): 1-18.

${ }^{13}$ Ramayulis and Mulyadi, 'BimBingan Konseling Islam Di Madrasah Dan SeKolah', in BimBingan Konseling Islam Di Madrasah Dan SeKolah, vol. 1 (Jl. Teladan No. 2 - Johar Baru V Jakarta Pusat - 10560: KAlam mUlia Jakarta, 2016), http://repository.uinib.ac.id/441/; Fibriana Miftahus Sa'adah and Imas Kania Rahman, 'Konsep Bimbingan Dan Konseling Cognitive Behavior Therapy (cbt) Dengan Pendekatan Islam Untuk Meningkatkan Sikap Altruisme Siswa', Hisbah: Jurnal Bimbingan Konseling dan Dakwab Islam 12, no. 2 (12 December 2015): 49-59, https://doi.org/10.14421/hisbah.2015.122-05.
} 
meaning with the meanings mentioned above, then two defenition will emerge, namely providing information and directing, leading to a goal.

Career guidance services are activities and assistance services to students with the aim of gaining adjustment, understanding the world of work and finally being able to to choose work and develop career planning. Career guidance services are the processes to help individuals in understanding and accepting themselves and secondly, help students to understand and adjust themself to the real world of work.

Thus, the most important thing in career guidance is the understanding, acceptance, and adjustment both to itself and to the world of work. Career guidance is given to students to plan and develop their future in terms of education and career. Career guidance services are services and approaches to individuals or students so that, the individual can get to know himself, recognize his potential, understand himself and to know the world of work, to plan his future with the life forms he hopes for, to make his choices and make a decision that the decision is the most appropriate and in accordance with his situation when connected with the requirements and demands of the job/career $\operatorname{chosen}^{14}$.

\section{Purpose of Career Guidance}

The purpose of career guidance is to help individuals for obtaining the competencies are needed, be able to find their life's journey and develop their careers in the direction they choose optimally and provide a complete information of the requirements of particular position, so that, students can understand it by themselves, be able to determine the direction of career choices and finally to help students in designing their future ${ }^{15}$. In addition, students can be prepared to work and have an independent attitude that can be relied upon to be able to face the globalization era competition and the challenges future careers as well as to create skilled workers to prepare themselves for entering the workforce by fulfilling competencies in various developments ${ }^{16}$. In general, the holding of career guidance in is senior high school, to help students in understanding themselves and their environment, in making decisions, planning, and directing activities that lead to careers and ways of life that provide a sense of satisfaction because it is appropriate, harmonious and balanced with himself and his environment ${ }^{17}$.

The specific objectives of career guidance for senior hing school are: 1) Students can distinguish in more detail the personality traits (abilities, special talents, interests, values, and personality traits) and be able to see the difference with others. Then he can identify areas and levels of work that might suit him. 2) Students can distinguish the various worlds of education available, which can provide preparation training for future work. This information can include the traits and purpose of each education available, opportunities to obtain it, and

${ }^{14}$ Muslim Afandi, 'Tipe Keribadian Dan Model Lingkungan Dalam Perspektif Bimbingan Karier John Holland', Sosial Budaya 8, no. 1 (2011): 86-96.

${ }^{15}$ Bimo Walgito, Bimbingan \& konseling perkahwinan (ANDI, 2017); Charles P. Chen and Joyce Wong, 'Career Counseling for Gifted Students', Australian Journal of Career Development 22, no. 3 (2013): 121-129.

16 Ulifa Rahma, Bimbingan Karier Siswa (Malang: UIN-Maliki Press, 2010), http://repository.uinmalang.ac.id/1232/.

${ }^{17}$ Vincy Jing Sun and Mantak Yuen, 'Career Guidance and Counseling for University Students in China', International Journal for the Advancement of Counselling 34, no. 3 (2012): 202-210; W. S. Winkel, Bimbingan dan konseling di institusi pendidikan (Media Abadi, 2005). 
tentative estimates of what is available to him as a possible choice of work in the future. 3) Students are able to identify future decisions that must be decided with a view to achieving certain different goals. 4) Students can distinguish among many jobs in terms of: 5) Students can choose or complete education or training on the basis of their career choices ${ }^{18}$.

The purpose of career guidance to help students is as follows: 1) Students can understand and assess themselves, especially those related to the potential that exists in himself regarding to abilities, interests, talents, attitudes and goals. 2) Recognizing and understanding the values that exist in themselves and society. 3) Knowing several of work that related to potential that exists in him, knowing types of education and training that needed for a particular field, and understanding the relationship between his current business with his future. 4) Find the obstacles that might arise caused by themselves and environmental factors and find ways to overcome these obstacles. 4) Students can plan for their future and find a career and life that is harmonious or appropriate ${ }^{19}$.

A job that is pioneered by someone during his life, which the work will get its way, in living a life full of responsibilities that is myself, family, siblings, people around me and so on.

\section{The Principles of Career Guidance}

So that, career guidance in senior high school can work as well as possible in accordance with the goals set, then, set some views about the principles of guidance need to be considered by supervisors, especially in school administrators in general, especially in preparing the implementation of career guidance programs in schools. In general the principles of career guidance in schools are ${ }^{20}$ :

All students should get the same opportunity to develop themselves in achieving their career correctly. All students have the same opportunity in using career guidance facility; there are no exceptions, both the rich and the poor. Every student has the same right to develop themselves to plan a career according to their abilities, through career guidance.

Every student should understand that career is a way of life, and education is a preparation for life. Career guidance provides students with an understanding of career, after graduation, they need a place to apply the knowledge they have studied at school. The career is used as means to achieve happiness in life and future. With career guidance students have independence in determining and choosing a career that can provide happiness in life and the future $e^{21}$.

Students should be assisted in developing adequate understandings of oneself and its relation to personal social development and career education planning. Self-understanding as a first step in planning a career gives encouragement for students to get to know and know everything that is in him. With self-understanding, students have the ability to determine and choose which career is suitable/appropriate and able to provide pleasure in living it.

\footnotetext{
${ }^{18}$ Syamsu Yusuf, Landasan Bimbingan Dan Konseling (Bandung: Remaja Rosdakarya, n.d.); Endang Switri, BIMBINGAN KONSELING ANAK USLA DINI (Penerbit Qiara Media, 2019).

${ }^{19}$ Walgito, Bimbingan \& konseling perkahwinan, 19.

${ }^{20}$ Winkel, Bimbingan dan konseling di institusi pendidikan.

${ }^{21}$ Xiaolu Zhou, Xixi Li, and Yaoming Gao, 'Career Guidance and Counseling in Shanghai, China: 1977 to 2015', The Career Development Quarterly 64, no. 3 (2016): 203-215; Valérie Cohen-Scali, Jerome Rossier, and Laura Nota, New Perspectives on Career Counseling and Guidance in Europe: Building Careers in Changing and Diverse Societies (Springer, 2017).
} 
Students are given an understanding of where and why they are in an education channel. As a whole, students should be helped to understand the relationship between their education and career. Students at each stage of their education program should have careeroriented and meaningful realistic career experiences. Every student should choose the opportunity to test their concepts, roles and skills in order to develop values and norms that have applications for his future career. Career guidance programs should have an aim to stimulate the development of student education. Career guidance programs in schools should be functionally integrated with educational programs in general and guidance program and counseling programs in particular ${ }^{22}$.

Dari beberapa prinsip-prinsip yang terdapat dalam bimbingan karir tersebut dapat disimpulkan bahwa bimbingan karir dalam pelaksanaannya memiliki pedoman yang umum dan jelas dalam memberikan pelayanan kepada siswanya dalam mendeteksi diri, memberikan layanan tentang dunia kerja sehingga mampu menciptakan kemandirian siswa dalam menentukan arah pilihan karir yang sesuai dengan keadaan dirinya, agar mampu mencapai kebahagiaan hidup di masa depan karirnya.

From some principles contained in career guidance, it can be concluded that career guidance is an implementation. It has general and clear guidelines in providing services to students in detecting themselves, providing services about the world of work, so as, to create student independence in determining the direction of appropriate career with his condition, in order to be able to achieve the happiness of life in the future of his career.

\section{RESEARCH METHODS}

The approach used in this research is the qualitative approach. This means that the data collected is not number, but data derived from interviews, observations, personal documents, notes, memos and documents that describe the empirical reality behind the phenomenon in depth, in detail and complete ${ }^{23}$.

This research uses qualitative methods. The type of qualitative method used is descriptive qualitative. Descriptive research is research that is intended to gather information about the status of an existing symptom, namely the state of symptoms according to what they were at the time, the study was conducted. As with the research model "Measurement After Event". Descriptive research is not intended to test certain hypotheses, but only describes "the reallity" about variable, symptom or situation ${ }^{24}$. It is only describing the meaning of the data or phenomena that can be captured by the researcher, by showing the evidence. The meaning of pheneomena depends on the abilities and progress of the researchers in analyzing it. According to Spradley, for highly skilled qualitative researchers, even a joke, he would be able to give meaning to a meaningful discovery. In conducting the analysis, the research actors ask various questions. so that, the meaning of a phenomenon in the description is made broad and sharp ${ }^{25}$.

\footnotetext{
${ }^{22}$ Ramayulis and Mulyadi, 'BimBingan Konseling Islam Di Madrasah Dan SeKolah'; J. Manuel Casas et al., Handbook of Multicultural Counseling (SAGE Publications, 2016).

${ }^{23}$ Moloeng Lexy J, Metodologi penelitian Kualitatif, 29th ed. (Bandung: Rosdakarya, 2011), 131.

${ }^{24}$ Patlima Hamid, Metode penelitian Kualitatif, Ed. 2 (Bandung: Alfabeta, 2011).

${ }^{25}$ Arikunto Suharsimi, Prosedur Penelitian, Suatu Pendekatan Teori dan Praktek, 14th ed. (Jakarta: Rineka Cipta, 2010).
} 
The primer data source in this study is the principal because he is responsible for all activities in the school, two counseling guidance teachers, and third grade (III) students, they are one hundred nine eight (198) students and they divided into (8) classes, where there are 6 Plus senior high school classes and (2) two are accelerated classes/accelerated programs, researchers took two (2) students in one (1) class. It multiplied by eight (8) classes. It is $(2 \times 4=$ 8 ), students are selected by counseling guidance teacher, The writer takes the students to check the answers given by the Counseling Guidance teacher and the principal, interviews with the students. The researchers took these people as research subjects because according to their researchers they were the people who were directly involved in implementing career guidance at Al-Azhar Senior High School in Medan. Secondary data sources from this study are documents about the implementation of career guidance services in class XII at Al-Azhar Senior High School in Medan in determining majors to the level of college.

\section{DISCUSSION}

Career guidance services for class XII in determining majors to the level of college at Al-Azhar Plus Senior High School Medan can be seen from 3 aspects. The three aspects are the preparation of career guidance services for class XII in determining majors to the level of college, the form of the implementation of career guidance services in class XII in determining majors to the level of college, then there are supporting and inhibiting factors in the implementation of career guidance services in class XII in determining majors to college levels. These three aspects become the main focus in seeing how the Al-Azhar Medan Plus Senior High School in implementing career guidance services for class XII in determining majors to the level of college. For more details, it can be described in the following description:

\section{Preparation of Career Guidance Services for Class XII at Al-Azhar Plus Senior High Schools in Determining Majors for college level}

In general, class XII experience confusion in determining their career in the future. That requires Counseling Gauidance teachers to try to provide services to help students overcome career confusion, especially on career problems faced by XII at Al-Azhar Plus Senior High School. One of the efforts made by Counseling Guidance teachers to overcome these problems, in providing career guidance services in schools.

In general the holding of career guidance in SMA / MA is to help students in selfunderstanding and their environment, in decision making, planning, and directing activities that lead to careers and ways of life that provide a sense of satisfaction because it is appropriate, compatible and balanced with himself and his environment. In this case also helps students in choosing the right majors in college after graduating from senior high school. Considering how important this career guidance service is, the counseling guidance teachers in SMA Plus Al-Azhar Medan have a preparatory process in implementing career guidance services.

Providing services for students in general at Al-Azhar Plus Senior High School Medan through several stages. In terms of preparation related to counseling guidance services at Al-Azhar Plus Senior High School, there was no special preparation. But before the teacher really provides career guidance services to students there are several steps that the 
counseling guidance teacher does to find out the general situation and condition of students. The stage is to conduct DCM (Checklist of Problems) to students. By giving DCM (Problem Checklist) to find out the problems that students have. Career guidance service preparation for class XII in determining majors to the level of study at Al-Azhar Senior Plus High School Medan through several stages as follows:

First, there is a problem check list (DCM) that is used to determine the extent to which students have confusion about their career goals. So, the teacher knows where the student's confusion lies in the problem of his career goals and determines the course at the college level.

Second, through testing the Scholastic Aptitude Test (TBS). From the results of this test students also know the results of the test and know their abilities, so when starting a career guidance service the teacher is easy to provide direction and input students to determine their choices going forward after graduating from high school.

\section{Implementation of Career Guidance Services for Class XII at Al-Azhar Plus Senior} High School Medan in Determining Departments to College Level

The implementation of career guidance services in class XII at Al-Azhar Plus High School in determining the majors to the lecture level can be concluded by the writer that the implementation of career guidance services is carried out with several activities, namely:

First, through information services. In providing information services, in addition to information and explanations directly from the teacher, there are also some activities. Such as giving motivation is done by giving stories to students related to other career paths, besides the counseling guidance teacher also tells related to educational journey and journey in pursuing a career to date. Then in providing material counseling guidance teacher explains/displays slides about job descriptions and institutions. Then provide information services by facilitating campus to be promoted to students. Campus representatives come and provide information related to the world of campus and lectures. Then also posted on the school information boards about information on several campuses that can be easily seen by students.

Second, in addition through information services, the implementation of career guidance services at Al Azhar Plus Senior High School Medan also through information gathering visits at various universities. So, the school goes on field trips to several well-known campuses in North Sumatra to find information about universities and how to enter the campus.

Third, in the implementation of career guidance services also carried out through group/individual discussions. Group discussions take place in class when there are empty hours and individually done outside the classroom such as in the counseling guidance room and in the mosque.

Supporting and Inhibiting Factors in the Implementation of Career Guidance Services for Class XII in Al-Azhar Plus Senior High School Medan in Determining Departments to College Level

The implementation of career guidance services for class XII in determining majors to the level of college at Al-Azhar Plus Senior High School Medan also has supporting and inhibiting factors. These factors influence the implementation of career guidance services at 
Al-Azhar Plus High School Medan. As for several supporting factors in implementation, based on the author's analysis that there are several supporting factors in the implementation of career guidance services in Al-Azhar Medan Plus High School, namely educators' human resources, especially good counseling guidance teachers, then the availability of personnel, support from parents and government, student input good, adequate facilities, shared commitment and consistency (all stakeholders) and support from the principal in running the program. Especially the homeroom teacher who helps students in providing information services related to information about universities and majors that are there and also related information about the existence of scholarship receipts or the like, and the high motivation of the students themselves.

The factors that support the implementation of career guidance services in Al-Azhar Plus Senior High School Medan are internal and external as explained by Ulifa Rahma, internal factors that can support the implementation of career guidance services are the abilities, talents and interests of students ${ }^{26}$. Which is seen in the ability and enthusiasm of students in learning and implementing guidance and is seen in the high motivation of the students themselves.

Although the process of implementing career guidance services at Al-Azhar Plus Senior High School in Medan has been carefully developed, but there are still obstacles. The author can conclude that inhibiting factors implementation of career guidance services in AlAzhar Medan Plus Senior High School are: First, the unavailability special hours and special schedules for career guidance, so that, guidance and counseling teachers must look for an empty classroom or teacher's hours that are not included, so that, causes not all classrooms are accessible and non-routine. Second the availability of counseling guidance teacher insufficient ${ }^{27}$.

\section{CONCLUSION}

The implementation of career guidance services for class XII at Al-Azhar Plus Senior High School Medan in determining the majors to the college level is done through the process of preparation, implementation and there are several factors that are supporting and inhibiting. The implementation of career guidance services in general has been well implemented. This can be shown as follows:

Preparation of career guidance services for class XII in determining majors to the level of college at Al-Azhar Plus Senior High School Medan; first, there is a problem check list (DCM) that is used to find out the extent which students have confusion about their career goals. Through the problem check list (DCM) the teacher knows where the student's confusion about his career goals and determines the major at the college level. Second is using testing scholastic talent test (TBS). The results of this test, students also know their abilities, so when starting a career guidance service, the teacher is easy to give advice and suggestion to students to determine their choices after graduating from high school.

Implementing career guidance services in class XII in determining majors to the level of college at Al-Azhar Plus Senior High School Medan seen from three programs, first:

\footnotetext{
${ }^{26}$ Ulifa Rahma, Bimbingan Karir Siswa,. hal. 44

27 Jenny Bimrose and Alan Brown, 'Mid-Career Progression and Development: The Role for Career Guidance and Counseling', in Handbook of Career Development (Springer, 2014), 203-222.
} 
information services, second: information gathering visits from many universities, third: group/individual discussions. The three programs are: First: information services through information and explanations from the teacher also through several activities. Such as giving motivation by telling stories, carrying out teaching units and information services by giving students such majors information available in university and choosing careers according to their ability also according to students' talents and interests, providing information through slide shows from campus, through campus information boards and expos that come to school. Second, is gathering information from various universities, the school makes field trips to several well-known universities in North Sumatra to find information about universities and how to enter the university. Third: group/individual discussions are carried out both in the classroom and outside the classroom.

Supporting and Inhibiting Factors in career guidance services in class XII in determining majors to the level of college at SMA Plus Al-Azhar Medan namely: first, supporting factors which are human resource, especially counseling guidance teachers, supporting from parents and government, student's input is good, adequate facilities, commitment and consistency all stakeholders and supporting from principal in running the program and high motivation from the students themselves. The two inhibiting factors are: first, the unavailability of special hours and special schedules for career guidance, so that, not all classrooms are accessible and not routine. Second is the availability of inadequate counseling guidance teachers.

\section{REFERENCES}

A. Rusdiana. Konsep Inovasi Pembelajaran. Bandung: Pustaka Setia, 2014.

Abdullah, Idi, and Safarina. Etika Pendidikan, Keluarga, Sekolah Dan Masyarakat. Cet. 2. Jakarta: PT Raja Grafindo, 2015.

Afandi, Muslim. 'Tipe Keribadian Dan Model Lingkungan Dalam Perspektif Bimbingan Karier John Holland'. Sosial Budaya 8, no. 1 (2011): 86-96.

Alkrdem, Mofareh Saeed, and Abdulaziz Saeed Alqahtani. 'Educational Management in the Light of Islamic Standards'. Journal of Education, Society and Bebavioural Science, 12 February 2016, 1-9. https://doi.org/10.9734/BJESBS/2016/22671.

Anisah, Laelatul. 'Kompetensi Profesional Konselor Dalam Penyelenggaraan Penelitian Tindakan Bimbingan Dan Konseling'. JURNAL KONSELING GUSJIGANG 2, no. 1 (3 August 2016). https://doi.org/10.24176/jkg.v2i1.557.

Anwar, M. Fuad. Landasan Bimbingan Dan Konseling Islam. Deepublish, 2019.

Asiah.T, Siti, and Herson Anwar. 'College Students' Perception about the Implementation of Democratic and Humanist Learning Model in State Islamic Institute (IAIN) Sultan Amai Gorontalo'. Nadwa 12, no. 2 (7 January 2019): 273-92. https://doi.org/10.21580/nw.2018.12.2.2713.

Asrori, Achmad. 'Contemporary Religious Education Model on the Challenge of Indonesian Multiculturalism'. JOURNAL OF INDONESLAN ISLAM 10, no. 2 (1 December 2016): 261-84. https://doi.org/10.15642/JIIS.2016.10.2.261-284.

Bimrose, Jenny, and Alan Brown. 'Mid-Career Progression and Development: The Role for Career Guidance and Counseling'. In Handbook of Career Development, 203-222. Springer, 2014. 
Bukhori, Baidi. 'Dakwah Melalui Bimbingan Dan Konseling Islam'. Jurnal Konseling Religi 5, no. 1 (2014): 1-18.

Casas, J. Manuel, Lisa A. Suzuki, Charlene M. Alexander, and Margo A. Jackson. Handbook of Multicultural Counseling. SAGE Publications, 2016.

Chen, Charles P., and Joyce Wong. 'Career Counseling for Gifted Students'. Australian Journal of Career Development 22, no. 3 (2013): 121-129.

Cohen-Scali, Valérie, Jerome Rossier, and Laura Nota. New Perspectives on Career Counseling and Guidance in Europe: Building Careers in Changing and Diverse Societies. Springer, 2017.

Darimis, Darimis. 'Rem-Bekas (revolusi Mental Berbasis Konseling Spritual Teistik): Upaya Membangun Generasi Berkarakter Fast (fathonah, Amanah, Siddiq, Dan Tabligh)'. Ta'dib 18, no. 1 (17 October 2016): 47-56. https://doi.org/10.31958/jt.v18i1.277.

Desmita. Psikologi perkembangan. Jakarta, Indonesia: PT Remaja Rosdakarya, 2013.

Fauzi, Niki Alma Febriana, and Ayub Ayub. 'Fikih Informasi : Muhammadiyah's Perspective on Guidance in Using Social Media'. Indonesian Journal of Islam and Muslim Societies 9, no. 2 (25 December 2019): 267-93. https://doi.org/10.18326/ijims.v9i2.267-293.

Hamid, Patlima. Metode penelitian Kualitatif. Ed. 2. Bandung: Alfabeta, 2011.

Lexy J, Moloeng. Metodologi penelitian Kualitatif. 29th ed. Bandung: Rosdakarya, 2011.

Mahfud, Choirul. 'Evaluation of Islamic Education Curriculum Policy in Indonesia'. Premiere Educandum: Jurnal Pendidikan Dasar Dan Pembelajaran 9, no. 1 (2019): 34-43.

Muhibbin Syah. Psikologi Pendidikan dengan pendekatan baru. 18th ed. Bandung: Remaja Rosdakarya, 2013.

Netrawati, Netrawati, Khairani Khairani, and Yeni Karneli. 'Upaya Guru BK untuk Mengentaskan Masalah-Masalah Perkembangan Remaja dengan Pendekatan Konseling Analisis Transaksional'. Islamic Counseling: Jurnal Bimbingan Konseling Islam 2, no. 1 (21 July 2018): 79-90. https://doi.org/10.29240/jbk.v2i1.463.

Plumeyer, Anja, Pascal Kottemann, Daniel Böger, and Reinhold Decker. 'Measuring Brand Image: A Systematic Review, Practical Guidance, and Future Research Directions'. Review of Managerial Science 13, no. 2 (1 April 2019): 227-65. https://doi.org/10.1007/s11846-017-0251-2.

Primayana, Kadek Hengki. 'Manajemen Sumber Daya Manusia Dalam Peningkatan Mutu Pendidikan Di Perguruan Tinggi'. Jurnal Penjaminan Mutu 1, no. 2 (2016): 7-15.

Purwanto, Yedi, Qowaid Qowaid, Lisa'diyah Ma'rifataini, and Ridwan Fauzi. 'Internalisasi Nilai Moderasi Melalui Pendidikan Agama Islam Di Perguruan Tinggi Umum'. EDUKASI: Jurnal Penelitian Pendidikan Agama Dan Keagamaan 17, no. 2 (31 August 2019). https://doi.org/10.32729/edukasi.v17i2.605.

Rahma, Ulifa. Bimbingan Karier Siswa. Malang: UIN-Maliki Press, 2010. http://repository.uinmalang.ac.id/1232/.

Ramayulis, and Mulyadi. 'BimBingan Konseling Islam Di Madrasah Dan SeKolah'. In BimBingan Konseling Islam Di Madrasah Dan SeKolah, Vol. 1. Jl. Teladan No. 2 - Johar Baru V Jakarta Pusat - 10560: KAlam mUlia Jakarta, 2016. http://repository.uinib.ac.id/441/. 
Riyadi, Agus. 'Bimbingan Dan Konseling Islam Dalam Mengatasi Krisis Spiritual Akibat Dampak Abad Modern (Studi Pada Lembaga Bimbingan Dan Konsultasi Tasawuf Kota Semarang)'. Konseling Religi: Jurnal Bimbingan Konseling Islam 9, no. 1 (2018).

Sa'adah, Fibriana Miftahus, and Imas Kania Rahman. 'Konsep Bimbingan Dan Konseling Cognitive Behavior Therapy (cbt) Dengan Pendekatan Islam Untuk Meningkatkan Sikap Altruisme Siswa'. Hisbah: Jurnal Bimbingan Konseling dan Dakwah Islam 12, no. 2 (12 December 2015): 49-59. https://doi.org/10.14421/hisbah.2015.122-05.

SINAMBELA, PARDOMUAN NJM. 'Kurikulum 2013 Dan Implementasinya Dalam Pembelajaran'. Generasi Kampus 6, no. 2 (2017).

Suharsimi, Arikunto. Prosedur Penelitian, Suatu Pendekatan Teori dan Praktek. 14th ed. Jakarta: Rineka Cipta, 2010.

Sun, Vincy Jing, and Mantak Yuen. 'Career Guidance and Counseling for University Students in China'. International Journal for the Advancement of Counselling 34, no. 3 (2012): 202-210.

Switri, Endang. BIMBINGAN KONSELING ANAK USLA DINI. Penerbit Qiara Media, 2019.

Walgito, Bimo. Bimbingan \& konseling perkabwinan. ANDI, 2017.

Wardi, Moh., Ismail Ismail, and Ali Makki. 'Perbandingan Pendidikan; Pemahaman Simbolis Dan Substantif PAI Di Madrasah Dan PAI Di Sekolah Umum'. Nidhomul Haq : Jurnal Manajemen Pendidikan Islam 4, no. 1 (7 March 2019): 23-33. https://doi.org/10.31538/ndh.v4i1.104.

Winkel, W. S. Bimbingan dan konseling di institusi pendidikan. Media Abadi, 2005.

Yusuf, Syamsu. Landasan Bimbingan Dan Konseling. Bandung: Remaja Rosdakarya, n.d.

Zhou, Xiaolu, Xixi Li, and Yaoming Gao. 'Career Guidance and Counseling in Shanghai, China: 1977 to 2015'. The Career Development Quarterly 64, no. 3 (2016): 203-215. 